DEBORTOLI N., DUBREUIL V., HIROTA M., RODRIGUES FILHO S., LINDOSO D., NABUCET J., 2017 : detecting deforestation impacts in southern amazonia rainfall using rain gauges. International Journal of Climatology. Vol.37, Issue 6, 2889-2900. DOI: 10.1002/joc.4886

\title{
Detecting deforestation impacts in Southern Amazonia rainfall using rain gauges
}

\author{
Nathan S. Debortoli, ${ }^{\text {ab,cc* } *}$ Vincent Dubreuil, ${ }^{\mathrm{b}}$ Marina Hirota, ${ }^{\mathrm{d}, \mathrm{e}}$ Saulo Rodrigues Filho, ${ }^{\mathrm{a}}$ \\ Diego P. Lindoso ${ }^{\mathrm{a}}$ and Jean Nabucet ${ }^{\mathrm{b}}$ \\ ${ }^{a}$ Center for Sustainable Development (CDS) University of Brasilia (UnB), Brazil \\ ${ }^{\mathrm{b}}$ LETG-Rennes-COSTEL (Climat et Occupation du Sol par Télédétection), Université Rennes 2, France \\ ${ }^{\mathrm{c}}$ Ecology Department, Federal University of Santa Catarina (UFSC), Brazil

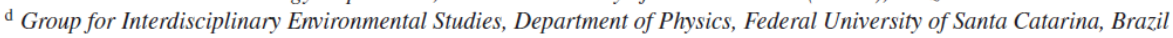 \\ ${ }^{e}$ Functional Ecology Lab, Department of Plant Biology, University of Campinas, Brazil
}

\begin{abstract}
During the last decades, several climate-modelling studies have forecasted a decrease in precipitation in Southern Amazonia, projecting scenarios of a drier Amazon for the future in relation with deforestation (or forest cover). In this area, only a limited number of analyses using forest cover data and rainfall time series have considered the transitional zones between the Amazon Forest and the Cerrado biome. In this work, we evaluated whether forest cover and rainfall patterns are correlated. The analysis encompassed rainfall times series from 207 rain gauges during the 1971-2010 period, and forest cover data acquired from LANDSAT5 satellite images. The results indicate that, at local level $(1-15 \mathrm{~km})$, both seasonal and annual precipitation values are not correlated to forest cover, whereas at the regional scale $(30-50 \mathrm{~km})$ contrasting to annual values, significant correlation occurs between forest cover and seasonal precipitation. Additionally, the study suggests that the larger the forest areas, the greater the probabilities of those influencing precipitation at regional scale, in opposite direction to the observed local level effects.
\end{abstract}

KEY WORDS Amazonia; buffer zones; Cerrado; correlation; deforestation; LANDSAT5; rain gauge; rainfall

Received 9 July 2015; Revised 24 July 2016; Accepted 16 August 2016

\section{INTRODUCTION}

\subsection{SEASONAL AND CLIMATIC PATTERNS IN SOUTHERN AMAZONIA}

Recent studies addressing the hydrological cycle in the Amazon Basin have confirmed a decrease in precipitation in Southern Amazonia (Spracklen et al. 2012; Debortoli 2013; Debortoli et al. 2015; Dubreuil et al. 2012; Davidson et al. 2012; Makarieva et al. 2012; Bonini et al. 2014). During the last 40 years, numerous hypotheses have supported and suggested that there is a relationship between the Amazon forest cover and the precipitation regime over the region, particularly in continental areas secluded from ocean moisture (Durieux, 2003; Espinoza-Villar, 2009; Fu and Li, 2004; Ramos da Silva et al. 2011; Callede et al. 2008; Costa, 2004; Salati et al. 1979; Makarieva et al. 2007, 2009, 2012). Some of these studies suggest that without the Amazon forest, South America southernmost regions could have a substantial decrease in moisture during austral summer (Davidson et al. 2012; Marengo et al. 2012; Costa et al. 2010; Da Rocha et al. 2011).

At the large atmospheric scale, rainfall in the Amazon basin is mostly driven by humidity, which is dragged from the Atlantic Ocean by the trade winds, and trapped over the region by the 
Andes Mountains and then released to other continental regions in South America (Sheil and Murdyarso, 2009; Pielke and Avissar, 1998; Gorshkov et al. 2004). Water vapor is also liberated through evapotranspiration (mostly through forest leaves), enhancing moisture flow into the atmosphere - the so-called biotic pump mechanism, considered a controversial theory (Makarieva et al. 2009). Part of this moisture flux flows southward and depending on its intensity and characteristics may configure the atmospheric pattern known as the South America Low Level Jet East of the Andes - SALLJ (Marengo et al. 2004; Poveda et al. 2014; Arraut et al. 2012). This system reaches the La Plata and Paraná basins mainly during austral spring (Marengo, 2006; Liebmann and Mechoso, 2011; Spracklen 2012) becoming crucial for the hydrological balance within these regions, especially during summer time (Poveda and Mesa, 1997).

In the southern Amazon (a transition zone between the Amazon and the Cerrado biomes) the rainy season is primarily controlled by the South American monsoon system, connected to the SALLJ, the South Atlantic Convergence Zone (SACZ) and the Bolivian high-pressure (Liebmann and Mechoso, 2011). This monsoon period is usually offset after the maximum seasonal temperature phase during the dry winter-season (high temperature peak). During this peak, moisture advection originated from ocean in continental regions is low, and the air excessively dry. Consequently, rain cloud formation at the early and late (onset/offset) stages of the rainy season is very much dependent on forest biologic, chemical and physical evapotranspiration mechanisms (Cox et al. 2008; Betts et al. 2008; Pölsch et al. 2010; Artaxo et al. 2001; Pohlker et al. 2012 and Rizzo et al. 2012).

Focusing on this issue, recent findings from modeling experiments for the period between 2001 and 2007 have revealed that air masses when crossing over the Amazon canopy, produce at least twice as much precipitation if compared to areas of Cerrado (Brazilian savannah), pastures or open herbaceous fields (Spracklen et al. 2012; Aragão, 2012). Empiric relationships between air masses and the current rates of deforestation have been shown to disable water-recycling mechanisms in deforested surfaces. Spracklen's study has estimated reductions in rainfall up to $12 \%$ in the rainy season and 21\% during the dry season for the year 2050 (Spracklen et al. 2012). Such findings claim that changes in rainfall patterns operate on time scales of days over distances from $100 \mathrm{~km}$ to $1000 \mathrm{~km}$, so, major changes in forest cover could also alter local rainfall regime through changes in thermodynamic and mesoscale circulation processes (Spracklen et al. 2012; Lawrence and Vandecar 2015). However, the deforestation model used by Spracklen's is considered pessimistic, since Brazil has pledged to limit historical rates of deforestation by $80 \%$ in 2020 . On the other hand, if deforestation does not fall as promised, the scenario is probably underestimated (Aragão, 2012).

\subsection{SOCIOECONOMIC AND ENVIRONMENTAL CONTEXTS}

Deforestation in Southern Amazonia is responsible for an important part of the balance between soil surface albedo and the atmosphere, especially in the Amazonian Arc of Deforestation region (Costa 2004; Costa et al. 2010). According to INPE (2012), more than 396,857 $\mathrm{km}^{2}$ of the Brazilian Amazon have been deforested between 1988 and 2012. The states accounting for most of this deforestation are: Mato Grosso, Pará and Rondônia (Figure 1). 


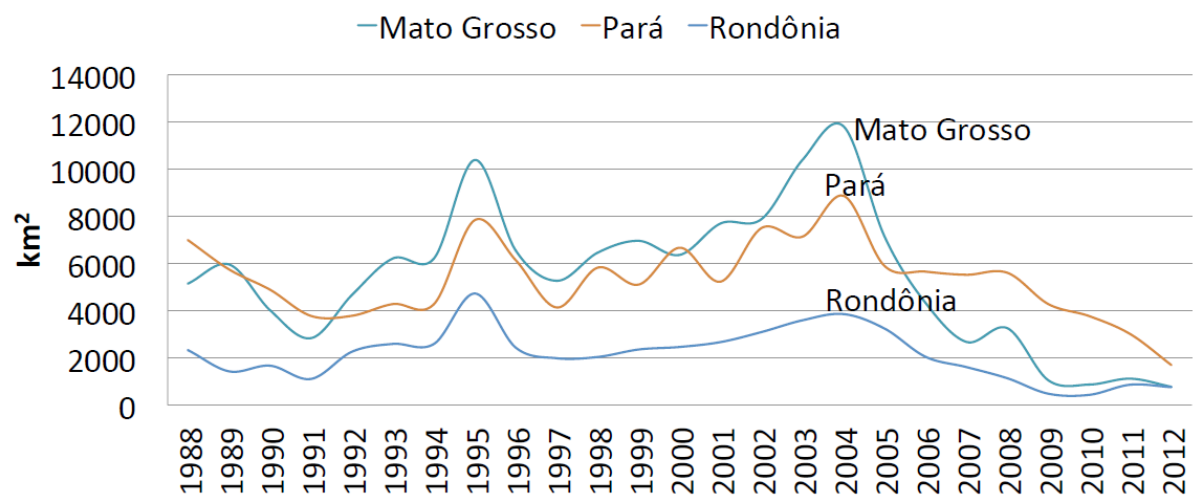

Figure 1 Accumulated deforestation rates in $\mathrm{km}^{2}$ (y-axis) for three states of the Legal Amazon (Mato Grosso, Pará and Rondônia) in the 1988-2012 period (x-axis). Data from PRODES monitoring deforestation in the Amazon. Source: Debortoli et al. (2015) adapted from PRODES / INPE (2012).

When deforestation allies to regional changes in climate it can increase the mortality of trees linked to drought (Phillips et al. 2009) reducing carbon deposits and increasing the risk of fires (Aragão et al. 2007; Aragão et al. 2008) which may reduce biodiversity threatening rain-recycling mechanisms. These effects when combined with large-scale atmospheric phenomena such as the Atlantic Dipole and El Niño Southern Oscillation anomalies, can induce extremely dry conditions to forest cover, as occurred in the drought episodes of 2005/2010 (Marengo et al. 2008; 2011) and 1997/1998 (Aragão et al. 2007) respectively.. Nonetheless, since 2006, due to the implementation of environmental policies, surveillance practices (against deforestation) and land regularization, deforestation rates have slowly decreased. Such tendencies have been observed especially in Southern Amazonia (Rosa et al. 2012; Lapola et al. 2011; 2013).

Nowadays the Amazon and Cerrado deforested areas (Arc of Deforestation) are responsible for a large part of the rain fed commodities agriculture in Brazil. Therefore, changes in water availability could represent a direct threat to agriculture that generates about US\$ 15 billion of revenues and to hydroelectric power plants, which provides $65 \%$ of Brazil's electricity power (Fearnside 2006; Fearnside and Pueyo 2012; Coe et al. 2013; Arvor et al., 2013).

Considering that a great amount of water used to allow agriculture and hydropower plants is recycled through evapotranspiration from the Amazon canopy, it is vital to understand to what extent forest fragmentation in Southern Amazonia could weaken local and regional hydrological cycle mechanisms. Such threat could jeopardize the adaptive capacity of populations to cope with changes in precipitation patterns. This could cause the abandonment of agricultural and traditional practices, provoking a falloff of local livelihoods such as extractive, indigenous, smallholding farming and fisherman populations (Nepstad et al. 2008; Saatchi et al. 2012; Marengo et al. 2012; Lapola et al. 2011). Moreover, drier conditions in regions of strong seasonality, if aggravated, may increase the probability of evergreen tropical forest areas to become prone to a more seasonal vegetation type such as the Dry Seasonal Forest and Savannah (Malhi et al. 2009; Oyama and Nobre 2003).

Thus to assess the contribution of forests to rainfall in Southern Amazonia during a 40year timeframe (1971-2010), this study correlated rainfall trends obtained from 207 Rain Gauges (RG) with forest cover data derived from satellite images. Spatial correlation techniques at different 
regional scales are used in order to show the relationships between forest cover and annual and seasonal precipitation patterns.

\section{Data and methodology}

\subsection{Forest cover data}

Satellite data was obtained from two different sources. For the Amazon region data was collected from PRODES DIGITAL/INPE (National Institute for Spatial Research) which covers all the Brazilian Amazon forest areas. For the Cerrado region (Brazilian Savannah) data was collected from the Center of Remote Sensing studies (SISCOM, acronym in Portuguese) from IBAMA (Brazilian Institute of Environment and Renewable Natural Resources). Both data sets had to be assembled/merged into a composite/mosaic of 30-m LANDSAT5 images that supported a full picture of the case study area. For the mosaic assembly phase a $100 \mathrm{~m}$ threshold was used in ArcGIS 10. The threshold of (100 m x $100 \mathrm{~m}$ ) (or $1 \mathrm{ha}$ ) was set to acquire high resolution in the data assembly and correctly identify changes in forest cover.

To capture all forested and water areas, a series of classified layers that could correspond and communicate to each other were exploited from INPE and IBAMA data sources. For both forest cover calculation layers (PRODES DIGITAL and IBAMA) we have used Natural Vegetation Loss up to 1997 (LOSS97), Natural Vegetation Loss between 1997-2010 (LOSS97-10) and Remaining Forest 2010 (FOR10) (see section 3 for methodology).

From INPE, we have considered the forest cover layers for 2010 in the states of Amazonas, Pará, Rondônia, Acre, Mato Grosso, Goiás and Tocantins. These layers depict the amount of forest cover and water polygons. For the Cerrado, we have considered the Cerrado and Pantanal layers from IBAMA. These IBAMA layers had to be merged (assembled) into INPE's because their polygon classification was done originally separated by SISCOM. Therefore, they were fused with: a deforested layer (anthropic), forest cover layer (reminiscent protected Cerrado or Pantanal vegetation) and the water layer. After the correction performed on all layers during the merging and assembling phase, the information was classified identically for the Amazon Forest, Cerrado and Pantanal biomes as: forest areas, non-forest and water.

Following the merging/assembling process, the study region, i.e. Southern Amazonia was defined as the area covering the Brazilian states of Mato Grosso and Rondônia, and their adjacent areas to the north, south, east and west, ranging from -6 to $-20 \mathrm{~S}$ of latitude and -47 to $-69 \mathrm{~W}$ of longitude.

\subsection{Rain gauge data and analyses}

We used the dataset from Debortoli et al. (2015) composed by 207 rain gauge stations (RGs), which were available for the southern Amazon region within the ANA's (2015) (Brazil's National Water Agency) platform called Hidroweb. In theory, to fulfil the recommendation of the World Meteorological Organization, we searched for time series with a minimum of 30 years of data. However, in some parts of the study region, the historical colonization occurred in $<40$ years, particularly within forested areas. The exclusion of these RGs was likely to affect the results of the correlation patterns for trend analyses we aimed at evaluating. Thus, because all 207 RGs presented at least 20 years of data, we decided to use 20 years as a minimum for the annual trend analyses, i.e. using 207 RGs (see Figure 2 to visualize the distribution of the RGs); and 27 years as a minimum 
for the rainy seasonal analyses, i.e. using 89 RGs (see more details on the selection on Appendix S1 and Debortoli et al., 2015). Moreover, such dataset had already been checked for consistency, using an adaptation of the method proposed by Fetter et al. (2012) (Appendix S1 and Debortoli et al., 2015).

Two trend analysis were performed: (1) Linear Regression Analyses (LRA) to account for temporal trends in annual totals, and rainy season onset and offset and length; and (2) the MannKendall (MK) approach to account for trends in the rainy season onset, offset and length, and also compare the results obtained by LRA. The trends identified here were then used as inputs in the correlation analyses with forest cover loss that will be described further.

To define the rainy season onset, offset and length, we used an approach adapted from Liebmann et al. (2007) (hereafter referred to as LB07) method. In the original LB07 method, the 'anomalous accumulation' value (AA) is computed, accounting for the accumulated anomalies calculated as the differences between daily precipitation time series values for each RG and the climatological annual daily average. The calculation starts 10 days prior to the beginning of the previously identified driest month and accounts for the sum for an entire year. Thus, the rainy season onset is defined as the day from which AA remains positive during the longest period found, whereas the offset occurs when AA reaches a maximum, i.e. after that day,AAstarts decreasing (Liebmann et al., 2007). The basic difference we applied was that here we chose the beginning of the rainy season as the day when AA is the minimum (and not a minimum before a certain number of consecutive positive values). The offset of the rainy season, on the other hand, followed LB07 method and was defined as the day when AA reaches a maximum. We have found this slight modification to be more appropriated to detect the onset and offset in the Southern Amazonia (we refer to Appendix S1, Section 2 andDebortoli et al., 2015 formore details on the methodology for the adaptation performed).

\subsection{Buffer analysis}

We propose a novel methodology to account for forest cover within different spatial scales based on the definition of buffer zones. It consists of using a buffer zone defined by: (1) a centroid given by each RG station coordinates, and (2) the surrounding neighbourhood given by a circular area with radius from centroid equals to $1,5,10,20,30,40$ and $50 \mathrm{~km}$ (e.g. a 50-km buffer represents roughly $7.850 \mathrm{~km} 2$ ). This methodology allows for the correlation analyses within different spatial scales, i.e. we are able to evaluate the impacts of vegetation cover (loss/remaining) in rainfall trends for various spatial scales (here, from local to regional scales).

Depending on the radius chosen, two or more buffer zones are likely to intersect each other. In this case, to avoid duplicated information for the correlation analyses, we performed an intersection procedure (from ArcGIS 10) to define an unique circumference around each as follows:

for each RG A, the area that intersected RG B considers all elements ofRGA that also belong toRGB (or equivalently, all elements ofRG B that also belong to RGA) but no other elements (see intersection details in Appendix S2).

Finally, we classified vegetation cover for each RG buffer zone (for each radius), accounting for deforested and forest areas, as: (1) LOSS97, (2) LOSS97-10, (3) FOR10 and (4) Water (Figure 2). 


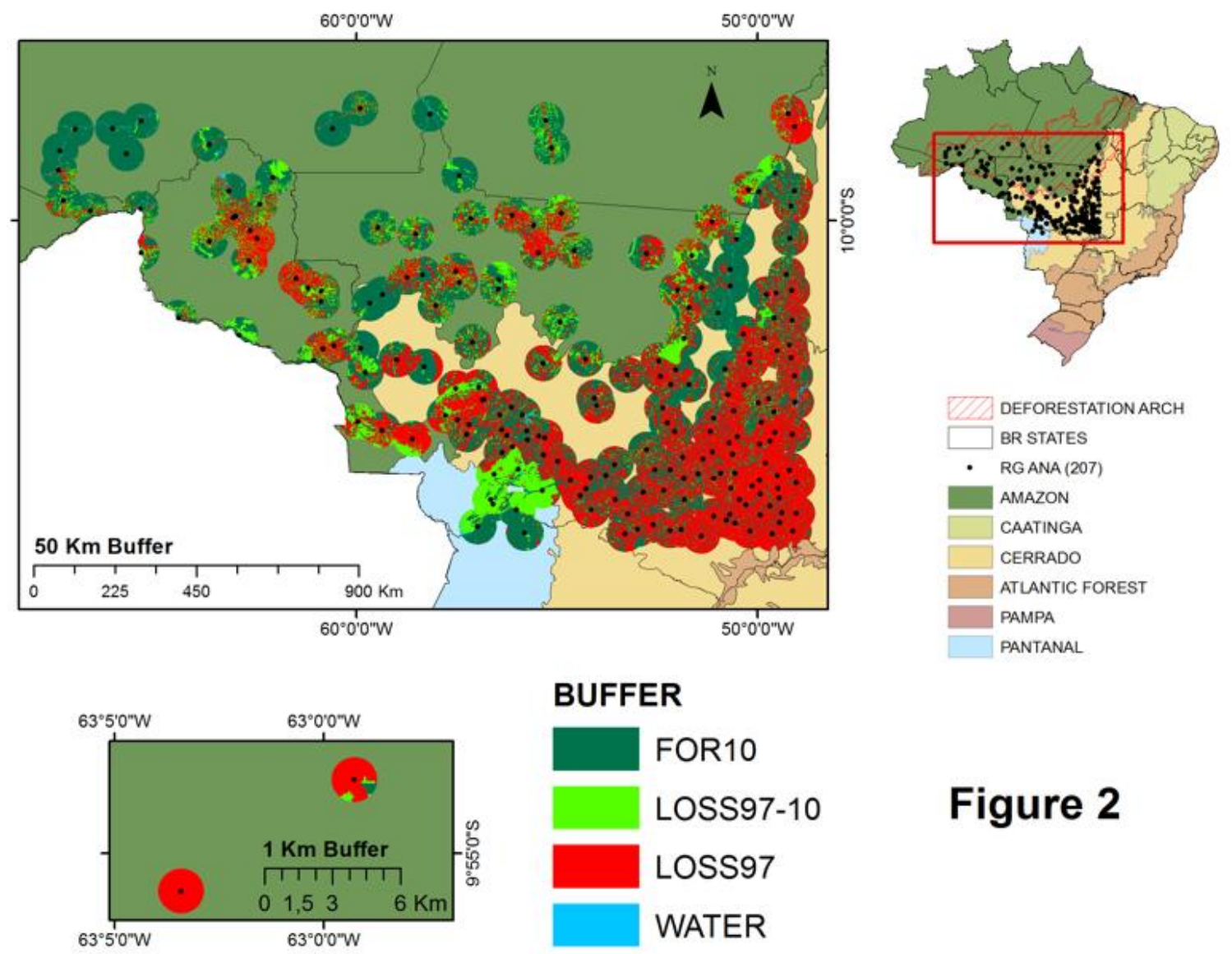

Figure 2 The Buffer Zones for 207 RG in Southern Amazonia. In the Brazilian map on the right, the localization of the RG within the biomes distribution. The bottom left map represents $1 \mathrm{~km}$ buffers (the smallest size) and the top left map represents $50 \mathrm{~km}$ buffers (the largest size). The maps show RG buffers land cover classification as follows: Dark Green = Remaining Forest 2010 $($ FOR10); Light Green = Natural Vegetation Loss between 97-10 (LOSS97-10) and Red = Natural Vegetation Loss up to 1997 (LOSS 97), Blue (Water). Source: Debortoli et al. (2015). Layers: IBAMA and IBGE.

\subsection{Correlation analyses}

The correlation between vegetation cover within the buffer zones (radius 1-50 km) and rainfall trends obtained from LRA (annual and rainy season onset, offset and length) and MK (rainy season onset, offset and length) analyses were conducted using Excel tables considering the scheme shown in Figure 3. Vegetation cover data in $\mathrm{km} 2$ were transformed to percentage $(\%)$ for the correlation analyses.

We calculated the Pearson correlation and evaluated its statistical significance (if the resulting p-value $\leq 0.05$ ) using the table of critical values for Pearson's $r$ for a two-tailed test, i.e. depending on the degrees of freedom (which depends on the number of RGs and buffer zones used - meaning 207 for the annual trend analysis and 89 for the rainy season trend analyses) and the Pearson's $r$ found (as exemplified in Table 1). 
We tested different combinations of correlation between vegetation cover and rainfall trends depending on the broad classification of biomes given by the IBAMA and PRODES maps, as follows: vegetation cover (LOSS97, LOSS97-10, FOR10) $\times(1)$ annual trends (LRA) for Amazon+ Cerrado (207 RGs) (2) annual trends (LRA) for Amazon and Cerrado separately (Amazon - 67 RGs and Cerrado - 140 RGs); (3) rainy season onset/offset trends (LRA/MK) for Amazon+Cerrado (89 RGs, where 33 for the Amazon and 56 for the Cerrado) and (4) rainy season length (MK) for Amazon+Cerrado (idem 3). Bold values throughout tables of Section 3 indicate cases where correlation is significant.

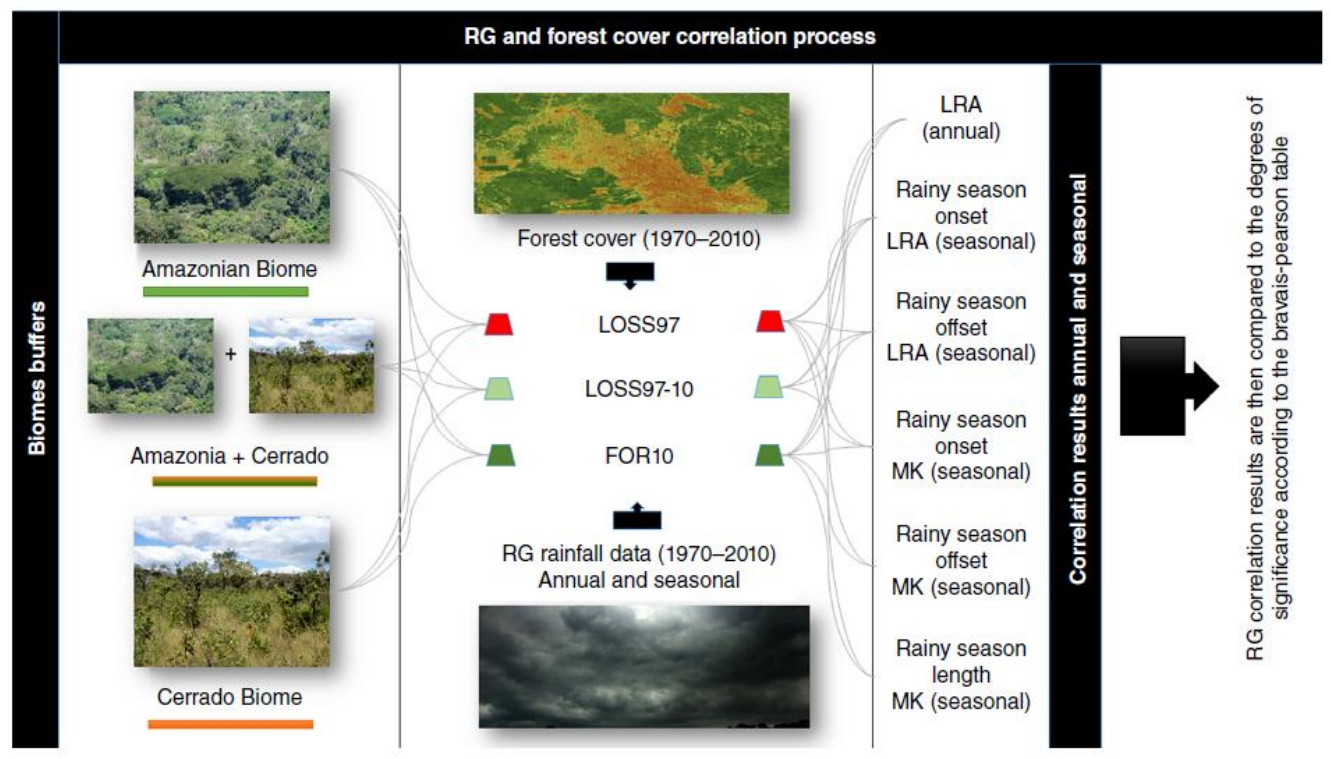

Figure 3 Correlation process methodology. On the left panel the biome combination options: Amazon+Cerrado, Amazon or Cerrado. On the center panel forest cover data and rainfall data are correlated in different time periods (FOR10; LOSS97-10, and LOSS97). The right panel indicates the combinations results for the annual LRA trends and for the LRA and MK seasonal climatic component for the onset/offset, and the rainy season's length. Source: Debortoli et al. (2015).

Table 1 Degree of correlation from the Odds Bilateral Critical Values of R Bravais-Pearson.

\begin{tabular}{|cccccccccc|}
\hline \multicolumn{10}{c|}{ Bravais Pearson Table } \\
\hline Rain Gauges Number & $\mathbf{0 , 2}$ & $\mathbf{0 , 1}$ & $\mathbf{0 , 0 5}$ & $\mathbf{0 , 0 2}$ & $\mathbf{0 , 0 1}$ & $\mathbf{0 , 0 0 1}$ & $\mathbf{0 , 0 0 0 1}$ & $\mathbf{0 , 0 0 0 0 1}$ \\
\hline 33 & 0,22210 & 0,28270 & 0,33400 & 0,39170 & 0,42980 & 0,53230 & 0,61020 & 0,67180 \\
\hline 50 & 0,18080 & 0,23080 & 0,27340 & 0,32190 & 0,35430 & 0,44340 & 0,51340 & 0,57080 \\
\hline 60 & 0,16510 & 0,21100 & 0,25020 & 0,29500 & 0,32500 & 0,40800 & 0,47400 & 0,52890 \\
\hline 80 & 0,14310 & 0,18310 & 0,21730 & 0,25670 & 0,28310 & 0,35700 & 0,41650 & 0,46660 \\
\hline 90 & 0,13500 & 0,17270 & 0,20510 & 0,24240 & 0,26740 & 0,33770 & 0,39460 & 0,44270 \\
\hline 100 & 0,12810 & 0,16390 & 0,19480 & 0,23020 & 0,25410 & 0,32120 & 0,37580 & 0,42210 \\
\hline 200 & 0,09070 & 0,11620 & 0,13820 & 0,16370 & 0,18100 & 0,23000 & 0,27050 & 0,30540 \\
\hline
\end{tabular}




\section{Results}

\subsection{Forest cover data}

Figure 2 shows examples of 1-km (small chart, lower left corner) and 50-km (larger chart) buffers zones. Forest cover classification indicates that areas to the north have more pristine natural cover (forest) when compared to those of the southeastern parts of the Cerrado natural vegetation. Figure 2 also indicates that the cores of recent deforestation are located in the southeastern border regions of the Xingú Park and northern areas of the Pantanal biome (depicted in light green in LOSS97-10 period - Figure 2). Buffers within pristine forest areas are mostly located in southeastern Amazonas and southwestern Pará at the edge with northern part of Mato Grosso state. From a local perspective using 1-5 km buffer zones, most of the study region presents intense deforestation both prior to 1997 and between 1997 and 2010 (LOSS97 and LOSS97-10). On the other hand, larger buffer zones 40-50 km show a more preserved frame, especially in the northern portions (e.g. Figure 2). If RGs are separated by the IBAMA biome classification, it is clear that there are proportionally more conserved areas in the Amazon than in the Cerrado. Yet, it is remarkable that substantial deforestation has occurred in the southern Amazon region during the period between 1997 and 2010. This is more significant between 10 and $13 \circ \mathrm{S}$ (in the states of Mato Grosso, Tocantins and Rondônia). In the Cerrado biome, for instance, the majority of the areas surrounding RGs were deforested prior to 1997, whereas northern region patches of native Cerrado vegetation are more preserved. It was also detected at local scale $(1-5 \mathrm{~km})$ that deforestation between 1997 and 2010 was intense in the Cerrado/Pantanal biome border around 14。S.

\subsection{Rainfall trend analyses}

LRA annual trend analyses reveal that $>60 \%$ of the 207 RGs show negative precipitation trends for the last 20-40 years, with the total range of precipitation change from -31.24 to $+35.30 \mathrm{~mm}$ along the 20-40 years (Figure 4). The spatial distribution of the trends (Figure 4) indicates that the majority of the higher positive precipitation trends occur in southern and southwestern Mato Grosso state and the southern part of the Amazonas state. On the other hand, negative tendencies are observed in the northwestern region of Rondônia, northern and southeastern Mato Grosso, northern Tocantins and Goiás states. It seems that the negative tendencies match the location more strongly affected by deforestation.

For the rainy season onset and offset analyses, the major impacts are observed in the offset with 75\% (LRA) and 76\% (MK) of the RGs showing an earlier offset. For the onset, we detected that $61 \%$ (LRA) and $84 \%$ (MK) of the RGs had a later onset. These results are comparable to Butt et al. (2011) and Funatsu et al. (2012) who found an average of a later shift of 11 days for the onset of the rainy season in deforested regions in the western Amazon (regional scale). Regarding the trend analysis for the rainy season length (using MK and LRA), the results indicated that of the 89 RGs, 88 and $79 \%$, respectively, had a shorter rainy season length.

\subsection{Correlation between forest cover and rainfall trends}

In this section, we show the correlation results between rainfall trends and the evolution of

forest cover in the various buffer zones around each RG. The results for the combinations shown in Figure 3 are presented in Tables 2-5. For illustration purposes, Tables 2-4 are depicted in Figure 5. Correlations throughout the tables when significant are represented in bold. The results for the 
annual LRA analysis (Table 2) indicated that the correlation within this trend was not significantwhen biomes are analysed and combined (Amazon+ Cerrado) or compared separately (Amazon Forest or Cerrado). The results seem to suggest that in the annual analysis, there is little correlation between forest cover and rain in most of the buffers.

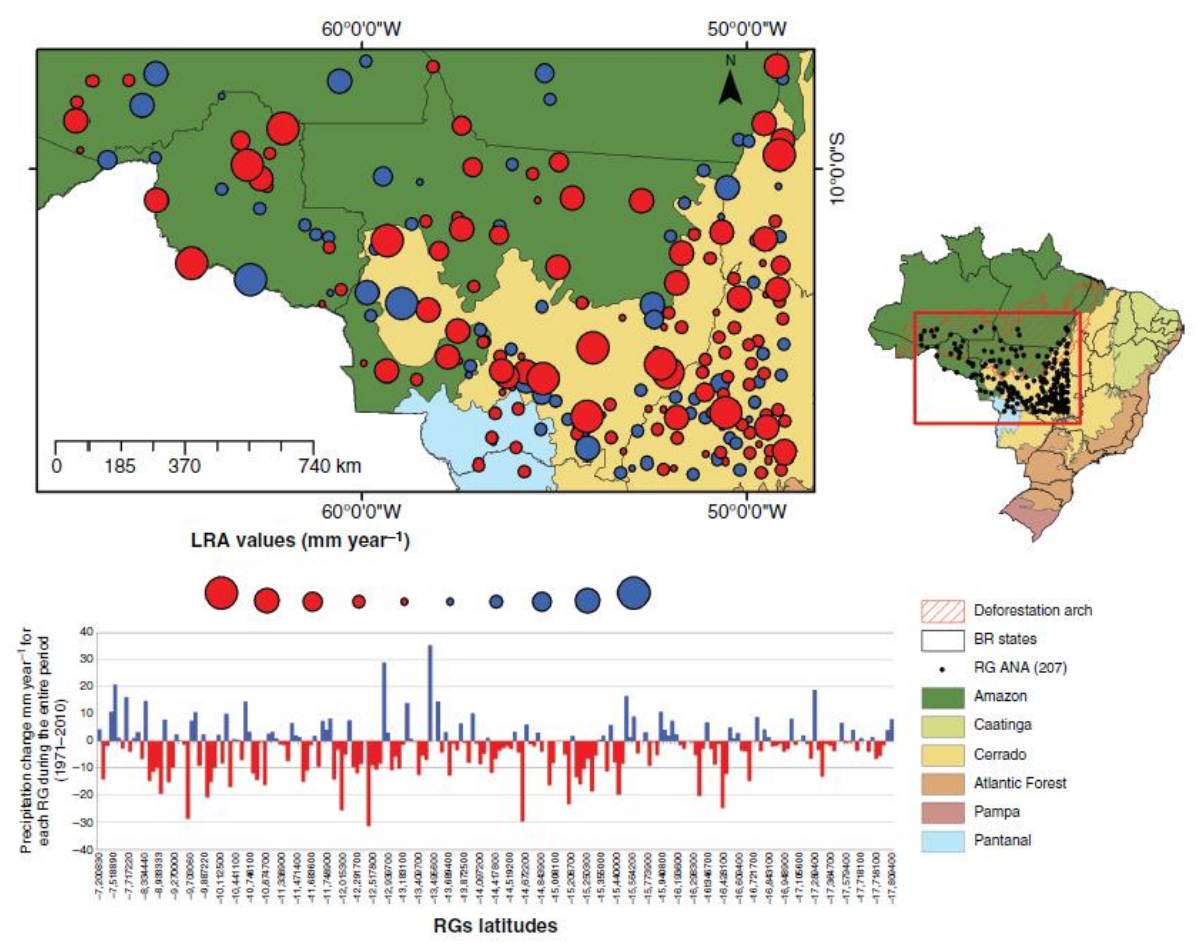

Figure 4 The map shows the distribution of precipitation patterns in the LRA analysis for the 207 RGs. In the Brazilian map on the right, the localization of the RGs within the biomes distribution. The bottom graph represents the Linear Regression Analysis (LRA) accumulated rainfall trends in $\mathrm{mm} /$ year for $207 \mathrm{RGs}$ during the 1971-2010 period. The RG are organized in the $\mathrm{x}$-axis from the lower latitude to the highest (-6S to -18S). In blue the RG that had a gain in precipitation and in red RG with a reduction in precipitation. Source: Debortoli et al. (2015).

For this reason, we have also conducted analysis considering the seasonal component of the precipitation time series. In this case, the rainy season onset does not show an important degree of correlation between forest cover and rain when compared to Pearson's degrees of freedom (Table 1). However, the season's offset indicated 0.2 and 0.1 degrees of significant correlation in the 89 RGs assessed. Therefore, the offset analysis considering the seasonal LRA and MK coefficients show significant correlation results as seen in Tables 3 and 4 (bold results). In the season's offset analyses, significant correlation values can be observed in Amazon+Cerrado FOR10, Amazon FOR10 and Cerrado FOR10 combinations. A similar pattern is observed in Amazon LOSS97 combination.

For the seasonal LRA analysis considering Amazon+ Cerrado FOR10 combination, correlation data were significant in $10 \mathrm{~km}$ buffers, and for Amazon FOR10, data were significant at $1 \mathrm{~km}$ buffers. For Amazon LOSS97-10 combination, the degree of correlation was significant at 50 $\mathrm{km}$ buffers. Also, the degrees of correlation in many cases increased in buffers from 1 to $50 \mathrm{~km}, 1$ 
to $10 \mathrm{~km}$ or 1 to $30 \mathrm{~km}$ and then decreased according to the buffer area (Table 3). Such scales impacts in precipitation are also discussed by Lawrence and Vandecar (2015) article.

Table 2 Correlation coefficients between mean annual rainfall in the LRA test analysis (annual values) and forest areas in each buffer zone $(1-50 \mathrm{~km})$. The correlation results are compared to the degree of correlation from the Odds Bilateral Critical Values of R Bravais-Pearson (Table 1). Amazon+Cerrado indicates that RGs in both biomes are counted (no. of RGs 207), than correlation is assessed for each biome, Amazon (no. of RGs 66) and for the Cerrado (no. of RGs 139).

\begin{tabular}{|c|c|c|c|c|c|c|c|c|c|}
\hline $\begin{array}{l}\text { Linear Regression } \\
\text { (LRA annual) }\end{array}$ & Period & $\begin{array}{l}\text { No. Rain } \\
\text { Gauges }\end{array}$ & $1 \mathrm{~km}$ & $5 \mathrm{~km}$ & $10 \mathrm{~km}$ & $20 \mathrm{~km}$ & $30 \mathrm{~km}$ & $40 \mathrm{~km}$ & $50 \mathrm{~km}$ \\
\hline Amazon +Cerrado & FOR10 & 207 & 0,0000058 & 0,00000055 & 0,000022 & 0,00012 & 0,00139 & 0,00122 & 0,00127 \\
\hline Amazon & FOR10 & 66 & 0,00563 & 0,00934 & 0,0111 & 0,02629 & 0,05363 & 0,05439 & 0,05661 \\
\hline Cerrado & FOR10 & 139 & 0,00452 & 0,005 & 0,00804 & 0,01147 & 0,01249 & 0,01433 & 0,01533 \\
\hline Amazon+Cerrado & $\begin{array}{c}\text { LOSS97- } \\
10 \\
\end{array}$ & 207 & 0,00015 & 0,0004 & 0,00049 & 0,0016 & 0,00077 & 70,00005 & 0,00029 \\
\hline Amazon & $\begin{array}{c}\text { LOSS97- } \\
10 \\
\end{array}$ & 66 & 0,00144 & 0,00731 & 0,0097 & 0,01066 & 0,0136 & 0,000011 & 10,00237 \\
\hline Cerrado & $\begin{array}{c}\text { LOSS97- } \\
10 \\
\end{array}$ & 139 & 0,0000019 & 0,00042 & 0,00056 & 0,0000083 & 30,00018 & 30,0004 & 0,00082 \\
\hline Amazon+Cerrado & LOSS97 & 207 & 0,00011 & 0,00015 & 0,00012 & 0,00111 & 0,0023 & 0,00183 & 0,00158 \\
\hline Amazon & LOSS97 & 66 & 0,00037 & 0,01571 & 0,02236 & 0,044 & 0,06511 & 0,06377 & 0,06101 \\
\hline Cerrado & LOSS97 & 139 & 0,00146 & 0,00456 & 0,00728 & 0,00693 & 0,00664 & $+0,00712$ & 0,00685 \\
\hline
\end{tabular}

Table 3 Correlation coefficients between the onset and offset of the rainy season in the LRA test analysis (seasonal values) and forest areas in each buffer zone $(1-50 \mathrm{~km})$. The correlation results are compared to the degree of correlation from the Odds Bilateral Critical Values of R Bravais-Pearson (Table 1). Amazon+Cerrado indicates that RGs in both biomes are counted (no. of RGs 89), than correlation is assessed for each biome, Amazon (no. of RGs 33) and for the Cerrado (no. of RGs 56). Bold (*) values indicate cases were correlation is more significant.

\begin{tabular}{|ccccccccccc|}
\hline $\begin{array}{c}\text { Rainy Season Onset and Offset } \\
\text { (LRA seasonal) }\end{array}$ & Period & $\begin{array}{c}\text { No. Rain } \\
\text { Gauges }\end{array}$ & $\mathbf{1 k m}$ & $\mathbf{5 k m}$ & $\mathbf{1 0 k m}$ & $\mathbf{2 0 k m}$ & $\mathbf{3 0 k m}$ & $\mathbf{4 0 k m}$ & $\mathbf{5 0 k m}$ \\
\hline Amazon+Cerrado Onset & FOR10 & 89 & 0,00569 & 0,03288 & 0,0424 & 0,04849 & 0,05323 & 0,06616 & 0,07634 \\
\hline Amazon+Cerrado Offset & FOR10 & 89 & 0,0625 & 0,0544 & $* \mathbf{0 , 1 3 1 3 7}$ & 0,11202 & 0,06935 & 0,0495 & 0,04304 \\
\hline Amazon Onset & FOR10 & 33 & 0,03427 & 0,08026 & 0,07829 & 0,0753 & 0,08018 & 0,09565 & 0,10159 \\
\hline Amazon Offset & FOR10 & 33 & $* \mathbf{0 , 2 1 5 4 7}$ & 0,15287 & 0,17055 & 0,13498 & 0,11275 & 0,08616 & 0,07084 \\
\hline Cerrado Onset & FOR10 & 56 & 0,00935 & 0,00148 & 0,00297 & 0,00376 & 0,000031 & 0,00001 & 0,0000048 \\
\hline Cerrado Offset & FOR10 & 56 & 0,00652 & 0,00798 & 0,07855 & 0,07441 & 0,04062 & 0,03086 & 0,03078 \\
\hline Amazon+Cerrado Onset & LOSS97-10 & 89 & 0,00217 & 0,00989 & 0,00855 & 0,00846 & 0,01119 & 0,01616 & 0,01493 \\
\hline Amazon+Cerrado Offset & LOSS97-10 & 89 & 0,00612 & 0,01451 & 0,0097 & 0,00178 & 0,00089 & 0,00289 & 0,00229 \\
\hline Amazon Onset & LOSS97-10 & 33 & 0,00958 & 0,00953 & 0,01006 & 0,00479 & 0,00535 & 0,0276 & 0,03082 \\
\hline Amazon Offset & LOSS97-10 & 33 & 0,3904 & 0,12062 & 0,10571 & 0,11595 & 0,14316 & 0,16804 & $* \mathbf{0 , 2 0 0 0 3}$ \\
\hline Cerrado Onset & LOSS97-10 & 56 & 0,02159 & 0,002 & 0,00188 & 0,00356 & 0,00295 & 0,00223 & 0,0021 \\
\hline Cerrado Offset & LOSS97-10 & 56 & 0,00036 & 0,00401 & 0,01188 & 0,04443 & 0,08245 & 0,09928 & 0,10135 \\
\hline Amazon+Cerrado Onset & LOSS97 & 89 & 0,01096 & 0,00791 & 0,01314 & 0,01865 & 0,01942 & 0,02359 & 0,03285 \\
\hline
\end{tabular}




\begin{tabular}{|ccccccccccc|}
\hline Amazon+Cerrado Offset & LOSS97 & 89 & 0,01606 & 0,0098 & 0,05125 & 0,07304 & 0,07362 & 0,06641 & 0,05525 \\
\hline Amazon Onset & LOSS97 & 33 & 0,08934 & 0,04448 & 0,04975 & 0,06837 & 0,07967 & 0,08249 & 0,09781 \\
\hline Amazon Offset & LOSS97 & 33 & 0,08693 & 0,02102 & 0,04406 & 0,04773 & 0,04272 & 0,02876 & 0,01888 \\
\hline Cerrado Onset & LOSS97 & 56 & 0,0184 & 0,000033 & 0,000097 & 0,000094 & 0,00203 & 0,00232 & 0,00161 \\
\hline Cerrado Offset & LOSS97 & 56 & 0,00022 & 0,01708 & 0,09757 & 0,17712 & 0,19936 & 0,2063 & 0,20104 \\
\hline
\end{tabular}

Table 4 Correlation coefficients between the onset and offset of the rainy season in the MK test analysis (seasonal values) and forest areas in each buffer zone $(1-50 \mathrm{~km})$. The correlation results are compared to the degree of correlation from the Odds Bilateral Critical Values of R Bravais-Pearson (Table 1). Amazon+Cerrado indicates that RGs in both biomes are counted (no. of RGs 89), than correlation is assessed for each biome, Amazon (no. of RGs 33) and for the Cerrado (no. of RGs 56). Bold (*) values indicate cases were correlation is more significant.

\begin{tabular}{|c|c|c|c|c|c|c|c|c|c|}
\hline $\begin{array}{l}\text { Rainy Season Onset and Offset } \\
\text { (MK seasonal) }\end{array}$ & & No. Rain Gauges & $1 \mathrm{~km}$ & $5 \mathrm{~km}$ & $10 \mathrm{~km}$ & $20 \mathrm{~km}$ & $30 \mathrm{~km}$ & $40 \mathrm{~km}$ & $50 \mathrm{~km}$ \\
\hline Amazon-Cerrado Onset & FOR10 & 89 & 0,00123 & 0,0189 & 0,02029 & 0,01214 & 0,00387 & 0,00235 & 0,0018 \\
\hline Amazon+Cerrado Offset & FOR10 & 89 & 0,02475 & 0,06141 & 0,12302 & $* 0,16648$ & $* 0,16426$ & $* 0,14539$ & $* 0,13249$ \\
\hline Amazon Onset & FOR10 & 33 & 0,00413 & 0,00997 & 0,00579 & 0,000036 & 0,00465 & 0,00726 & 0,00796 \\
\hline Amazon Offset & FOR10 & 33 & 0,04671 & 0,12808 & 0,18316 & 0,18514 & $* 0,20489$ & 0,17393 & 0,1551 \\
\hline Cerrado Onset & FOR10 & 56 & 0,00000018 & 0,02715 & 0,03732 & 0,04026 & 0,02786 & 0,02351 & 0,02067 \\
\hline Cerrado Offset & FOR10 & 56 & 0,0063 & 0,01684 & 0,06685 & 0,13 & $* 0,16426$ & 0,08663 & 0,07674 \\
\hline Amazon + Cerrado Onset & $\begin{array}{c}\text { LOSS97- } \\
\quad 10\end{array}$ & 89 & 0,00746 & 0,02569 & 0,01457 & 0,01166 & 0,01135 & 0,01166 & 0,00881 \\
\hline Amazon+Cerrado Offset & $\begin{array}{c}\text { LOSS97- } \\
10\end{array}$ & 89 & 0,00327 & 0,00605 & 0,00623 & 0,00294 & 0,00073 & 0,00021 & 0,00045 \\
\hline Amazon Onset & $\begin{array}{c}\text { LOSS97- } \\
10 \\
\end{array}$ & 33 & 0,01531 & 0,02457 & 0,00673 & 0,00077 & 0,000047 & 0,00078 & 0,000012 \\
\hline Amazon Offset & $\begin{array}{c}\text { LOSS97- } \\
10\end{array}$ & 33 & 0,00375 & 0,01439 & 0,03845 & 0,06175 & 0,10182 & 0,12092 & 0,1504 \\
\hline Cerrado Onset & $\begin{array}{c}\text { LOSS97- } \\
10 \\
\end{array}$ & 56 & 0,03648 & 0,02952 & 0,02284 & 0,02306 & 0,02357 & 0,02219 & 0,01991 \\
\hline Cerrado Offset & $\begin{array}{c}\text { LOSS97- } \\
10\end{array}$ & 56 & 0,00266 & 0,00552 & 0,00193 & 0,000047 & 0,00391 & 0,00682 & 0,00748 \\
\hline Amazon+Cerrado Onset & LOSS97 & 89 & 0,000086 & 0,00012 & 0,00183 & 0,00071 & 0,00024 & 0,0008 & 0,00048 \\
\hline Amazon+Cerrado Offset & LOSS97 & 89 & 0,01701 & 0,0286 & 0,06263 & 0,11321 & $* 0,13273$ & *0,13013 & 0,11873 \\
\hline Amazon Onset & LOSS97 & 33 & 0,01541 & 0,000076 & 50,00116 & 0,000024 & 0,00495 & 0,01162 & 0,01082 \\
\hline Amazon Offset & LOSS97 & 33 & 0,0503 & 0,08233 & 0,10306 & 0,11847 & 0,13368 & 0,11953 & 0,10072 \\
\hline Cerrado Onset & LOSS97 & 56 & 0,00706 & 0,000019 & 0,0008 & 0,00038 & 0,000099 & 0,00035 & 0,00032 \\
\hline Cerrado Offset & LOSS97 & 56 & 0,0007 & 0,00173 & 0,02486 & 0,08513 & 0,10064 & 0,10058 & 0,09141 \\
\hline
\end{tabular}

In the MK offset seasonal analysis results (Table 4) correlations were also significant. For the Amazon+Cerrado FOR10, they were significant in 20-50 km buffers increasing from 1 to 20 $\mathrm{km}$ buffers and decreasing from 20 to $50 \mathrm{~km}$ buffers. At the Amazon FOR10 offset correlation results were significant in $30 \mathrm{~km}$ buffers increasing from 1 to $30 \mathrm{~km}$ buffers and decreasing from there. The Cerrado FOR10 combination also showed some degree of correlation at $30 \mathrm{~km}$ buffers. The Amazon+Cerrado LOSS97 combination presented correlation at 30-40 km buffers.

It seems that at the $30 \mathrm{~km}$ buffer correlations have a more significant pattern, tending to increase at this rate, and then, decrease during the onset and offset analysis, even when correlation results did not reach significant correlation values using Pearson's method (Table 4). The rainy 
season length analysis comprising MK and LRA results (Table 5) had no significant correlations. Yet, the data depicted the same increasing patterns observed in Table 2, with more expressive values. The pattern can also be observed in the following data combination: Amazon+Cerrado FOR10, Amazon FOR10, Amazon+ Cerrado LOSS97, Amazon LOSS97 and Cerrado LOSS97.

Correlations even though not very significant in the rainy season length analysis, indicate thresholds in the influence of radius/land cover scales above or between 20,30, and $50 \mathrm{~km}$ (regional level) buffers, corroborating to previous results derived from large-scale circulation modelling studies (Davidson et al., 2012; Spracklen et al., 2012).

Table 5 Correlation coefficients for the Rainy Season Duration (seasonal values) in the LRA+MK tests and forest areas in each buffer zone $(1-50 \mathrm{~km})$. The correlation results are compared to the degree of correlation from the Odds Bilateral Critical Values of R Bravais-Pearson (Table 1). Amazon+Cerrado indicates that RGs in both biomes are counted (no. of RGs 89), than correlation is assessed for each biome, Amazon (no. of RGs 33) and for the Cerrado (no. of RGs 56). Bold values indicate cases were correlation is more significant.

\begin{tabular}{|c|c|c|c|}
\hline $\begin{array}{c}\text { Rainy Season Duration } \\
\text { (LRA+MK) }\end{array}$ & Period & No. Rain Gauges & $20 \mathrm{~km} \quad 30 \mathrm{~km} \quad 40 \mathrm{~km} \quad 50 \mathrm{~km}$ \\
\hline Amazon+Cerrado & FOR10 & 89 & $0,001070,000760,004570,019150,026050,026240,02641$ \\
\hline Amazon & FOR10 & 33 & 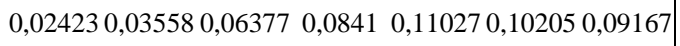 \\
\hline Cerrado & FOR10 & 56 & $0,000730,029170,029060,005070,005880,003760,00144$ \\
\hline Amazon+Cerrado & LOSS97-10 & 89 & $0,000980,005680,003470,002190,001770,001550,00106$ \\
\hline Amazon & LOSS97-10 & 33 & $0,109110,014810,033420,048490,070780,083980,11126$ \\
\hline Cerrado & LOSS97-10 & 56 & $0,000580,050590,052980,042940,039910,039940,04547$ \\
\hline Amazon+Cerrado & LOSS97 & 89 & $0,000370,007050,010610,026160,033070,034070,03334$ \\
\hline Amazon & LOSS97 & 33 & $0,000850,013720,020730,040740,061230,063820,05151$ \\
\hline Cerrado & LOSS97 & 56 & 0,006530,00305 0,004820,019330,016840,019920,0296 \\
\hline
\end{tabular}

\section{Discussion}

Findings concerning rainfall data (Debortoli et al., 2015) had previously indicated an earlier rainy season offset in Southern Amazonia. These findings are consistent with the correlations results we have found for the rainy season's offset. Therefore, the buffer analysis main results express: (1) in a local perspective buffers from 1 to $5 \mathrm{~km}$ are more deforested if compared to $50 \mathrm{~km}$ buffers; (2) annual LRA analysis correlation results are not significant in Amazon+Cerrado, Amazon or Cerrado combinations analysis; (3) the rainy season 'offset' correlations considering LRA analysis show significant results in Amazon+Cerrado FOR10 for $10 \mathrm{~km}$ buffers, Amazon FOR10 for $1 \mathrm{~km}$ buffers and Amazon LOSS97-10 for $50 \mathrm{~km}$ buffers; when considering MK analysis, the results were significant for Amazon+Cerrado FOR10 in 20, 30, 40 and $50 \mathrm{~km}$ buffers, Amazon FOR10 for $30 \mathrm{~km}$ buffers, Cerrado FOR10 for $30 \mathrm{~km}$ buffers and Amazon+Cerrado LOSS97 for 30 and $40 \mathrm{~km}$ buffers; (4) finally buffers with $>30 \mathrm{~km}$ had more significant correlation patterns.

Thus, it seems like the dry season might be increasing in these regions concomitant to the description of Costa and Pires (2010). According to Costa and Pires, the combination of deforestation in the Amazon and the Cerrado in governance and business as usual scenarios can cause an increase in the extent of the dry season by at least 1 month in the Arc of Deforestation. Accumulated deforestation in these regions is high, causing less evapotranspiration rates, and 
consequently, drying the atmosphere, which may delay the onset of the rainy season (extending the length of the dry period).

Experiments such as the one conducted by Funatsu et al. (2012) examined the annual cycle and time series of monthly evolution of the mean convective activity and its interannual variability in Mato Grosso state using Advanced Microwave Sounding Unit and Tropical Rainfall Measuring Mission. Their findings show that most of convective parameter tendencies are negative, suggesting a shift to drier conditions. Their study also suggests a tendency in recent years, showing a delay in the onset of the rainy season but without taking into account (as we did here) differentiate vegetation types.

In agreement with our results, Funatsu et al. (2012) also found a decrease in rainfall rates in the last decade. However, most of their results show higher correlations between forest cover and rainfall during the onset of the rainy season (but not for the offset), indicating higher values of convection over forested areas from February to June as opposed to deforested regions. These results are similar to our seasonal correlation analyses between RG and forest cover, which depicted higher correlation values in forested areas as opposed to deforested during seasonal periods.

(a)

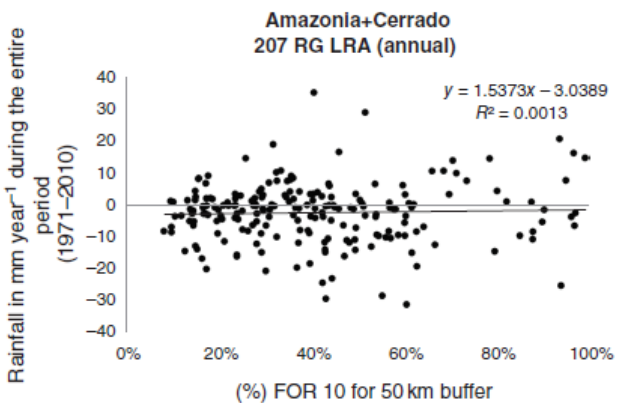

(c)

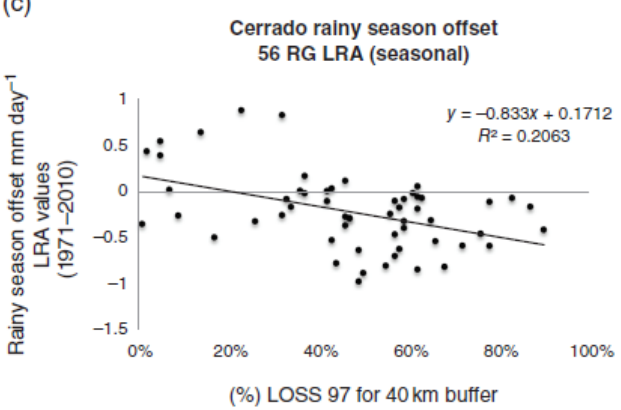

(b)

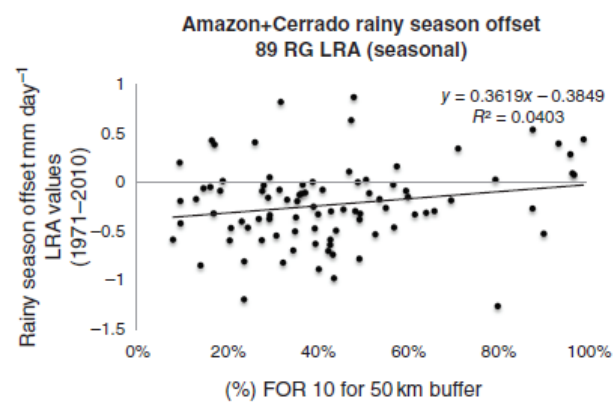

(d)

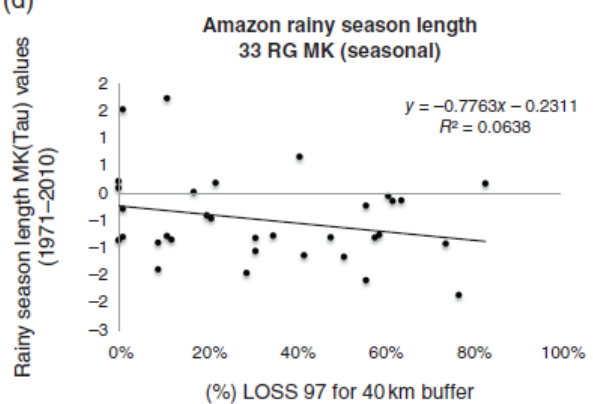

Figure 5 Graphs representing the correlations between some rainfall parameters trends (y-axis) and forest cover (x-axis). The A graph shows the correlation for 207-RG in the LRA annual analysis for both Amazonia+Cerrado combination. The B graph shows the correlation for 89-RG in the offset LRA rainy season analysis considering Amazonia+Cerrado combination. The $\mathrm{C}$ graph shows the correlation for 56-RG considering the rainy season's offset LRA seasonal analysis for the Cerrado biome. The D graph shows correlation for 33-RG considering the rainy season's length MK seasonal $t$ values for the Amazon biome. Source: Debortoli et al. (2015). 


\section{Final remarks}

Few studies have been dedicated to analyse the impact of land use on local and regional rainfall patterns in the Arc of Deforestation region. This area is particularly important for at least three reasons: first, it has the longest dry season in the Amazon Basin; secondly, it has the highest deforestation rates in the Amazon; and thirdly, its vegetation is particularly sensitive to changes in the length of the dry period (Aragão et al., 2007, 2008; Costa and Pires, 2010). Forests seem likewise fundamental in the protection of ecosystem services and conservation of ecosystem flows maintaining a healthy climate balance (Laurance et al., 2011).

Deforestation effects on climate vary considerably in this region depending on whether it is considered the Amazon rainforest as a whole or just the Arc Deforestation zones. Therefore, a reduction in precipitation depends on both tropical forest and Cerrado adjacent deforestation. For Lawrence and Vandecar (2015), large forest areas are important in the dynamics of wind shear, air turbulence and the potential precipitation due to the thermo-dynamical engine enrolled in transforming sensible heat to latent heat through the vegetation leaves, leaf area and forest canopy.

Numerical simulation studies showed that deforestation in large scales could lead to a vegetation breeze effect resulting in local increase in precipitation in deforested areas. Hence, fragmented deforestation could enhance an initial increase in precipitation, which would locally protect drier ecosystems (Avissar and Schmidt, 1998; Correia et al., 2008; Walker et al., 2009; Davidson et al., 2012). Yet, after a certain deforestation level (like the one found in the buffer analysis $30-50 \mathrm{~km}$ ) this condition could become unsustainable, leading to drier conditions and reduced precipitation (Costa et al., 2007; Sampaio et al., 2007; Laurance et al., 2011).

Correlating buffer-zone-forest-cover and rainfall data demonstrates that at local level forest areas were not statistically correlated with the annual historical precipitation trends, but to some extend relevant to seasonal patterns (rainy season offset). In the Cerrado biome for instance, correlations are weak and do not show significance in $90 \%$ of cases. Albeit negligible in most cases, the correlations indicate that the larger the buffer area is, the greater the degree of correlation between land use and atmosphere. However, because this study was limited to remote sensing techniques and RG collected data, we cannot confirm that precipitation is correlated to forest cover changes in Southern Amazonia. The study is limited to suggest that large-scale deforestation may have a larger impact on precipitation distribution and the physics related to large-scale circulation dynamics in Southern Amazonia, particularly during the offset of the rainy season, which could increase the length of the dry season.

This study therefore also indicates that transitional zones of the Amazon biome (dense canopy) to Cerrado (savanna physiognomies: from woodlands to open grasslands) imply in local particularities due to the physical implications of surface in the atmosphere. So, there is a great impact of the forest canopy on evapotranspiration, if compared to savanna areas in atmospheresurface interactions (Von Randow et al., 2012); also, areas to the south of the case study region are more influenced by cold fronts with a smaller role of evapotranspiration during the dry season (winter) (Siqueira and Machado, 2004).

Other variables not incorporated in this buffer study could ascent as strong indicators to be correlated with forest cover alone, such as evaporation rates or specific humidity. Also, despite of the numerous RG analysed in this study, their location to the east and south of the case study (due to the recent context of colonization of the area) could mask data from stations placed in areas of rainforest and transitional forest (less numerous). In the future, a more extensive network of RG 
(when available) could more precisely test this hypothesis. It should also be relevant to compare the dry and rainy seasons as separated cases in forest cover and rainfall correlations.

Regardless of the deforestation impacts on rainfall, we reinforce that extensive forest areas are crucial to control the incidence of radiation reaching the surface, and thus, support the maintenance of less extreme temperatures in forest environments by increasing levels of relative humidity. Therefore, within its limitations, this study contributes to bridge gaps on local and regional analyses comprising RG data and forest cover at climatic transitional zones.

Appendices S1 and S2 in Supporting Information provides explanations for RGs consistency check, the rainy season onset-offset methodology, and the intersection tests methodology and results used to correlate precipitation to forest cover.

\section{Acknowledgements}

The authors wish to thank the French National Agency for Research (ANR) which funded the DURAMAZ2 project (grant agreement ANR-11-BSH1-0003) and the European Union which funded the H2020-MSCA-RISE-2015 ODYSSEA project (Project Reference: 691053).

\section{REFERENCES}

ANA - Agência Nacional de Águas. Hidroweb: http://hidroweb.ana.gov.br

Aragão L. 2012. Environmental science: The rainforest's water pump. Nature, v. advance online publication, p. 14764687.

Aragão L, Malhi Y, Barbier N, et al. 2008. Interactions between rainfall, deforestation and fires during recent years in the Brazilian Amazonia. Philosophical Transactions of the Royal Society of London B: Biological Sciences 363:1779-1785.

Aragão LEOC, Malhi Y, Roman-Cuesta R, Saatchi S, Anderson LO \& Shimabukuro YE. 2007. Spatial patterns and fire response of recent Amazonian droughts. Geophys. Res. Lett. 34, L07701. (doi:10.1029/ 2006GL028946)

Arraut JM, Nobre C, Barbosa HMJ, et al. 2012. Aerial Rivers and Lakes: Looking at Large-Scale Moisture Transport and Its Relation to Amazonia and to Subtropical Rainfall in South America. Journal of Climate 25:543-556. doi: 10.1175/2011JCLI4189.1

Artaxo P et al. 2001. Links between the terrestrial biosphere and the atmosphere: a case example in Amazonia. Eighth European Symposium on the Physico-Chemical Behaviour of Atmospheric Pollutants. Torino-Italy: Institute for Environment and Sustainability, JRC EC - Biodiversity and Global Change Unit, DG Research, EC.

Artusi R, Verderio P, Marubini E. 2002. Bravais-Pearson and Spearman correlation coefficients: Meaning, test of hypothesis and confidence interval. International Journal of Biological Markers 17:148-151.

Arvor D, Dubreuil V, Ronchail J, Meirelles MS, Funatsu B. 2013. Spatial patterns of rainfall regimes related to levels of double cropping agriculture systems in Mato Grosso (Brazil). International Journal of Climatology. pp.1-12. http://onlinelibrary.wiley.com/doi/10.1002/joc.3863/abstract ; DOI: 10.1002/joc.3863

Arvor D, Meirelles MSP, Dubreuil V, Shimabukuro YE. 2012. Analyzing the agricultural transition in Mato Grosso, Brazil, using satellite-derived indices, Applied geography $\mathrm{n}^{\circ} 32$ pp.702-713 doi:10.1016/j.apgeog.2011.08.007; http://www.sciencedirect.com/science/article/pii/S0143622811001603

Avissar R and Schmidt T. 1998. An evaluation of the scale at which ground-surface heat flux patchiness affects the convective boundary layer using a large-eddy simulation model, J. Atmos. Sci., 55, 2666-2689, doi:10.1175/1520 0469(1998)055<2666:AEOTSA>2.0.CO;2.

Betts A and Silva Dias M .2010. Progress in understanding land-surface-atmosphere coupling from LBA research. $J$. Adv. Model. Earth Syst. v. 2. 
Bonini I, Rodrigues C, Dallacort R, et al. 2014. Rainfall and deforestation in the municipality of Colíder, southern Amazon. Revista Brasileira de Meteorologia 29:483-493. doi: 10.1590/0102-778620130665

Brienen R et al. 2012. Oxygen isotopes in tree rings are a good proxy for Amazon precipitation and El NinoSouthern Oscillation variability. Proceedings of the National Academy of Sciences, v. 109, n. 42, p. 16957-16962. ISSN 0027-8424.

Butt N, de Oliveira PA and Costa MH. 2011. Evidence that deforestation affects the onset of the rainy season in Rondonia, Brazil, J. Geophys. Res., 116, D11120, doi:10.1029/2010JD015174.

Callede J et al. 2008. Deboisement Amazonien: Son influence sur le debit de l'Amazone à Óbidos (Bresil). Revue des Sciences de l'Eau, v. 21, n. 1, p. 59-72.

Coe MT, Costa MH, Nepstad DC et al. 2013. Dependence of hydropower energy generation on forests in the Amazon Basil at local and regional scale. PNAS 2-6.

Correia FWS, Alvala RCS and Manzi AO. 2008. Modeling the impacts of land cover change in Amazonia: A regional climate model (RCM) simulation study, Theor. Appl. Climatol., 93, 225-244, doi:10.1007/s00704-0070335-z.

Costa M and Pires G. 2010. Effects of amazon and Central Brazil deforestation scenarios on the duration of the dry season in the arc of deforestation. International Journal of Climatology 30(13): 1970-1979.

Costa M. 2004. Large-scale hydrologic impacts of tropical forest conversion. In: Bonell, M., Bruijnzeel, L.A. (Eds.), Forests-Water-People in the Humid Tropics. Cambridge University Press, Cambridge (in press).

Costa MH, Yanagi SNM, Souza PJOP, Ribeiro A and Rocha EJP. 2007. Climate change in Amazonia caused by soybean cropland expansion, as compared to caused by pastureland expansion, Geophys. Res. Lett., 34, L07706, doi:10.1029/2007GL029271

Cox $\mathrm{P}$ et al. 2008. Increasing risk of Amazonian drought due to decreasing aerosol pollution. Nature, v. 453, n. 7192, p. 212-215.

Da Rocha RP, Cuadra SV, Reboita MS et al. 2011. Effects of RegCM3 parameterizations on simulated rainy season over South America. Climate Research.

Davidson E et al. 2012. The Amazon basin in transition. Nature, v. 481, n. 7381, p. 321-328. ISSN 0028-0836.

Debortoli N, Dubreuil V, Funatsu B, et al. 2015. Rainfall patterns in the Southern Amazon: a chronological perspective (1971-2010). Climatic Change. doi: 10.1007/s10584-015-1415-1

Debortoli N, Dubreuil V, Rodrigues-Filho S. 2013. Régime des pluies et déforestation en Amazonie Méridionale. Rennes, Université Rennes 2.

Dubreuil V et al. 2012. Impact of land-cover change in the Southern Amazonia climate: a case study for the region of Alta Floresta, Mato Grosso, Brazil. Environmental Monitoring and Assessment, v. 184, n. 2, p. 877-891, 2012. ISSN 0167-6369.

Dubreuil V, Arvor D, Debortoli N. 2012. Monitoring the pioneer frontier and agricultural intensification in Mato Grosso using SPOT Vegetation images. Bulletin de la société française de photogrammétrie, (200) 2-10.

Durieux L. 2002. Étude des relations entre les caractéristiques géographiques de la surface et les nuages convectifs dans la région de l'arc de déforestation en Amazonie. (Thèse de Doctorat). Université d'Aix-Marseille I, Marseille, France.

Espinoza J. 2009. Impact de la variabilité climatique sur l'hydrologie du bassin amazonien. Université Pierre et Marie Curie - Paris VI.

Fearnside P and Pueyo S. 2012. Greenhouse-gas emissions from tropical dams. Nature Clim. Change, v. 2, n. 6, p. 382-384. ISSN 1758-678X.

Fearnside P. 2006. Dams in the Amazon: Belo Monte and Brazil's hydroelectric development of the Xingu River Basin. Environmental management, v. 38, n. 1, p. 16-27. ISSN 0364-152X.

Fu R and Li W. 2004. The influence of the land surface on the transition from dry to wet season in Amazonia. Theoretical and Applied Climatology. Wien; New York, v. 78, n. 1, p. 97, 2004. ISSN 0177-798X. 
Fu R and W Li .2004. The influence of the land surface on the transition from dry to wet season in Amazonia, Theor. Appl. Climatol., 78, 97-110, doi:10.1007/s00704-004-0046-7.

Funatsu BM, Dubreuil V, Claud C, Arvor D and Gan MA. 2012. Convective activity in Mato Grosso state (Brazil) from microwave satellite observations: Comparisons between AMSU and TRMM data sets. Journal of Geophysical Research: Atmospheres. 117.

Gorshkov VG, Makarieva AM, Gorshkov V V. 2004. Revising the fundamentals of ecological knowledge: the biotaenvironment interaction. Ecological Complexity 1:17-36. doi: 10.1016/j.ecocom.2003.09.002

Hauke J, Kossowski T. 2011. Comparison of Values of Pearson's and Spearman's Correlation Coefficients on the Same Sets of Data. Quaestiones Geographicae 30:87-93. doi: 10.2478/v10117-011-0021-1

IBAMA - Instituto Brasileiro do Meio Ambiente e dos Recursos Naturais Renováveis - SISCOM: http://siscom.ibama.gov.br/monitorabiomas/

INPE - Instituto Nacional de Pesquisas Espaciais: Prodes Digital: http://www.obt.inpe.br/prodes/index.php

Kendall, MG. 1976. Rank Correlation Methods. 4th Ed. Griffin.

Lapola DM, Martinelli LA, Peres CA, et al. 2013. Pervasive transition of the Brazilian land-use system. Nature Climate Change 4:27-35. doi: 10.1038/nclimate2056

Lapola DM, Schaldach R, Alcamo J, et al. 2011. Impacts of climate change and the end of deforestation on land use in the Brazilian Legal Amazon. Earth Interact Earth Interactions 15:1-29.

Laurance W et al. 2011. The fate of Amazonian forest fragments: A 32-year investigation. Biological Conservation. v. 144, n. 1, p. 56-67. ISSN 0006-3207.

Lawrence D, Vandecar K. 2015. Effects of tropical deforestation on climate and agriculture. Nature Climate Change $5: 27-36$.

Liebmann B and Mechoso C. 2011. The South American Monsoon. In: (Ed.). The Global Monsoon System: Research and Forecast. 2nd World Scientific Publishing Co. cap. 9, p.137-157.

Makarieva A, Gorshkov V, Li B. 2012. Revisiting forest impact on atmospheric water vapor transport and precipitation. Theoretical and Applied Climatology. 111, 79-96.

Makarieva AM, Gorshkov VG, Li BL 2009 Precipitation on land versus distance from the ocean: Evidence for a forest pump of atmospheric moisture. Ecol Complex Ecological Complexity 6:302-307.

Makarieva AM, Gorshkov VG. 2007. Biotic pump of atmospheric moisture as driver of the hydrological cycle on land. Hydrol. Earth Syst. Sci. 11, 1013-1033

Malhi Y, Aragão L, Galbraith D, Huntingford C, Fisher R, Zelazowski P, Sitch S, Mcsweeney C, Meir P. 2009. Exploring the likelihood and mechanism of a climate-change-induced dieback of the Amazon rainforest. Proc. Natl. Acad. Sci., 106, 20610-20615.

Marengo J et al. 2008. The Drought of Amazonia in 2005. Journal of Climate, v. 21, n. 3. ISSN 0894-8755.

Marengo J et al. 2012. Recent developments on the South American monsoon system. International Journal of Climatology, v. 32, n. 1, p. 1-21. ISSN 0899-8418.

Marengo J, Soares WR, Saulo C, Nicolini M. 2004. Climatology of the Low-Level Jet East of the Andes as Derived from the NCEP-NCAR Reanalyses: Characteristics and Temporal Variability. Journal of Climate 17:2261-2280. doi: 10.1175/1520-0442(2004)017<2261:COTLJE>2.0.CO;2

Marengo J. 2006. On the hydrological cycle of the Amazon Basin: A historical review and current state-of-the-art. Revista Brasileira de Meteorologia, v. 21, n. 3, p. 1-19.

Marengo JA, Tomasella J, Alves LM, et al. 2011. The drought of 2010 in the context of historical droughts in the Amazon region. Geophysical Research Letters 38:

Nepstad D et al. 2008. Interactions among Amazon land use, forests and climate: prospects for a near-term forest tipping point. Philosophical transactions of the Royal Society of London. Series B, Biological sciences, v. 363, n. 1498, p. 1737-1746. ISSN 0962-8436.

Oyama MD and Nobre CA. 2003. A new climate-vegetation equilibrium state for Tropical South America. Geophys. Res. Lett. 30, 2199. 
Phillips OL, Aragao L, Lewis SL, Fisher JB, Lloyd J, Lopez-Gonzalez G, Malhi Y, Monteagudo A, Peacock J, Quesada CA et al. 2009. Drought sensitivity of the Amazon Rainforest. Science 323: 1344-1347

Pielke RA, Avissar R et al. 1998. Interactions between the atmosphere and terrestrial ecosystems: influence on weather and climate. Global Change Biology 4:461-475.

Pohlker C, Wiedemann KT, Sinha B, et al. (2012) Biogenic Potassium Salt Particles as Seeds for Secondary Organic Aerosol in the Amazon. Science 337:1075-1078.

Poschl U et al. 2010. Rainforest aerosols as biogenic nuclei of clouds and precipitation in the Amazon. Science, v. 329, n. 5998, p. 1513-1516.

Poveda G, Jaramillo L, Vallejo LF. 2014. Seasonal precipitation patterns along pathways of South American lowlevel jets and aerial rivers. Water Resources Research 50:98-118. doi: 10.1002/2013WR014087

Poveda G, Mesa OJ. 1997. Feedbacks between hydrological processes in tropical South America and large-scale ocean-atmospheric phenomena. Journal of Climate 10:2690-2702. doi: 10.1175/1520 0442(1997)010<2690:FBHPIT>2.0.CO;2

Ramos Da Silva R et al. 2011. Cloud streets and land-water interactions in the Amazon. Biogeochemistry, v. 105, n. 1-3, p. 201-211.

Rizzo LV, Artaxo P, Arana A, et al. 2012. Long term measurements of aerosol optical properties at a pristine forest site in Amazonia. Atmospheric Chemistry and Physics Discussions 12:23333-23401.

Rosa I, Souza C and Ewers R. 2012. Changes in size of deforested patches in the Brazilian Amazon. Conservation Biology: the Journal of the Society for Conservation Biology, 26, 5, 932-7.

Roy SB and Avissar R. 2002. Impact of land use/land cover change on regional hydrometeorology in Amazonia, $J$. Geophys. Res., 107(D20), 8040, doi:10.1029/2000JD000263

Saatchi S et al. 2012. Persistent effects of a severe drought on Amazonian forest canopy. Proceedings of the National Academy of Sciences. ISSN 0027-8424.

Salati E et al. 1979. Recycling of water in the Amazon Basin: An isotopic study. Water Resources Research, v. 15, n. 5. ISSN 0043-1397.

Sampaio G, Nobre C, Costa MH, Satyamurty P, Soares-Filho BS and Cardoso M. 2007. Regional climate change over eastern Amazonia caused by pasture and soybean cropland expansion, Geophys. Res. Lett., 34, L17709, doi:10.1029/2007GL030612.

Sheil D and Murdiyarso D. 2009. How Forests Attract Rain: An Examination of a New Hypothesis. bisi BioScience 59:341-347.

Siqueira J R and Machado LAT. 2004. Influence of the frontal systems on the day to day convection variability over South America, J. Clim., 17, 1754-1766, doi:10.1175/1520-0442(2004)017<1754: IOTFSO>2.0.CO;2.

Spracklen D, Arnold S and Taylor C. 2012. Observations of increased tropical rainfall preceded by air passage over forests. Nature, v. 489, p. 282-286.

Von Randow R et al. 2012. Evapotranspiration of deforested areas in central and southwestern Amazonia. Theoretical and Applied Climatology. V. 109, Issue 1-2, pp 205-220. ISSN 0177-798X.

Walker R, Moore NJ, Arima E, Perz S, Simmons C, Cladas M, Vergara D and Bohrer C. 2009. Protecting the Amazon with protected areas, Proc. Natl. Acad. Sci. U. S. A., 106, 10,582-10,586, doi:10.1073/ pnas.0806059106. 